Bangladesh J. Plant Taxon. 26(1): 69-81, 2019 (June)

(C) 2019 Bangladesh Association of Plant Taxonomists

\title{
MICROMORPHOLOGICAL AND ANATOMICAL INVESTIGATION ON SIX SPECIES OF ONOSMA L. (BORAGINACEAE) FROM TURKEY
}

\author{
Selami Selvi, Ridvan Polat ${ }^{1}$, Ebru Yuce Babacan ${ }^{2}$, M. Oliur Rahman ${ }^{3}$ \\ AND UĞUR ÇAKILCIOĞLU ${ }^{2,4}$ \\ Ballkesir University, Altınoluk Vocational School, Programme of Medicinal and \\ Aromatic Plants, 10870 Edremit-Ballkesir, Turkey
}

Keywords: Onosma L.; Micromorphology; Anatomy; SEM; Turkey.

\begin{abstract}
Micromorphology and anatomy of six Onosma L. species, viz. O. argentata Hub.Mor., O. neglecta Riedl, O. proballanthera Rech. f., O. rechingeri Riedl, O. sericea Willd. and $O$. stenoloba Hausskn. ex Riedl from Turky were investigated. Stem anatomy revealed that cuticle layer ranged from $0.6 \mu \mathrm{m}$ in $O$. argentata to $1.7 \mu \mathrm{m}$ in $O$. proballanthera. Parenchymatous cells of $O$. neglecta and $O$. stenoloba possessed more intense starch than the other species studied. In leaf anatomy, the longest palisade parenchyma was found in $O$. neglecta, while the smallest was noted in O. argentata. Mesophyll structure of $O$. argentata, $O$. sericea and $O$. rechingeri was equifacial (isobilateral), while $O$. neglecta, $O$. proballanthera and $O$. stenoloba presented bifacial (dorsiventral) structure. Rugose nutlet ornamentation was observed in O. argentata, $O$. neglecta and $O$. sericea, whereas reticulate type was found in $O$. proballanthera, $O$. rechingeri and $O$. stenoloba. Onosma stenoloba could easily be distinguished from other species by its aesterotrichous indumentum, and in contrary, other species possessed haplotrichous type of indumentum. Micromorphological features of nutlet surface, anatomical features of epidermal surface (trichomes and stomata), and lamina mesophyll structure (dorsiventral and isobilateral) could be useful in solving taxonomic problem of the genus.
\end{abstract}

\section{Introduction}

Onosma L. belonging to the family Boraginaceae consists of about 150 species, distributed mainly in West and Central Asia and in the Mediterranean area, and grows in dry, sunny, rocky, sandy, and steppe habitats (Cecchi and Selvi, 2009; Binzet et al., 2010, Kolarcik et al., 2010). Onosma are biennial or perennial herbs, characterized by scorpioid cymes, linear or linearlanceolate calyx lobes that are parted to base, corolla without ribs or deep furrows, unappendaged corolla throat, sagittate anthers coherent at base, capitate stigma and ovate to triangular nutlets. Cronquist (1981) included the family Boraginaceae in the Order Lamiales of the sub-class Asteridae of Magnoliopsida. Güner et al. (2012) states that the Boraginaceae stands the ninth position among the families in Turkey in term of number of species, and is represented by 44 genera and 375 taxa in the flora of Turkey. One hundred and three endemic taxa represent approximately 50\% of the Onosma taxa in Turkish flora (Güner et al., 2012; Binzet, 2016). The indumentum of leaves and stem of Onosma taxa consists of three separate components: setae (rarely hairs) often slightly raised, or pancake-shaped with multicellular tubercles; setules, sometimes shortened to tiny spinules or produced as hairs, stellately arranged around the base of

\footnotetext{
${ }^{1}$ Bingöl Universtiy, Genç Vocatinal School, Bingöl, Turkey.

${ }^{2}$ Munzur University, Pertek Sakine Genç Vocational School, Tunceli, Turkey.

${ }^{3}$ Department of Botany, University of Dhaka, Dhaka 1000, Bangladesh. Email: oliur.bot@du.ac.bd

${ }^{4}$ Corresponding Author: ucakilcioglu@ yahoo.com
} 
the seta; and tiny hairs forming a pubescent, puberulous or tomentose surface covering between the setae. The setae provide the plant its typically hispid indumentum and they are brittle and easily detached, penetrating the skin and causing an irritant rash (Riedl, 1978). The members of Onosma are medicinally important and considered as cardiotonic, purgative, anthelmintic, and used for treatment of diabetes, leucoderma, dyspepsia, abdominal pain, and bronchitis (Hayta et al., 2014; Özgen et al., 2004). In addition, they are economically important for beekeeping because of their attractive flowers, and rich in nectar (Dukas and Dafni, 1990).

Taxonomic significance of micromorphology and anatomy in delimitation of taxa and establishment of interspecific relationships are well documented (Tschan and Denk, 2012; Meng and Mao, 2013; Begum et al., 2014). Metcalfe and Chalk (1950) studied the anatomy of the family Boraginaceae and found setae (hairs), epidermal surface and cystoliths as diagnostic characters. Several attempts have been made on micromorphology and anatomy of different Turkish species of Onosma (Akçin and Engin, 2001, 2005; Akçin, 2004, 2007; Binzet and Akçin, 2009; Akçin and Binzet, 2010). Micromorphological studies of epidermal and nutlet surface of some Onosma taxa highlighted the importance of these features (Akçin, 2009; Binzet and Akçin, 2009; Akçin et al., 2013; Mehrabian et al., 2014).

In the present study, the micromorphological and anatomical structure of six species of Onosma, namely $O$. argentata, $O$. neglecta, $O$. proballanthera, $O$. rechingeri, $O$. sericea and $O$. stenoloba from Bingöl and its environs of Turkey were investigated for the first time. Morphological characters are controlled by the genes of a species as well as influenced by phenotypic plasticity, and because of these phenomena proper identification of species sometimes become problematic. In this regard, micromorphology and anatomical studies provide powerful tools for species delimitation and interspecific relationship. The main objectives of the present study are two folds: i) to explore the anatomical features of stem, leaf and epidermal surface of six Turkish Onosma species, and ii) to investigate stem, leaf and nutlet micromorphology by scanning electorn microscopy of those species which could contribute to the taxonomy of Onosma.

\section{Materials and Methods}

\section{Plant materials}

Six Onosma species were collected from natural habitats of Bingöl, Turkey from 2016 to 2017. The taxonomic identity of the species were confirmed following Riedl $(1967,1978)$. The list of the species employed in this study along with their Turkish names, localities and vouchers are presented in Table 1. The voucher specimens have been deposited at the Munzur University Herbarium.

\section{Anatomical studies}

Anatomical studies were carried out on specimens kept in $70 \%$ ethanol. Cross-sections of stem and leaves were stained with Phloroglucinol-HCl, toluidin, safranine and lugol's solution and the chlorophyll pigments in leaves were removed with chloral hydrate (Yakar-Tan, 1982; Selvi et al., 2014). After dyeing, the sections were prepared as permanent slides and examined under the light microscope Olympus BX53 with photograph attachment, and the photographs were taken and digitized. Stomatal density on abaxial and adaxial surfaces of the leaves were counted under a light microscope. Stomatal index were calculated following Meidner and Mansfield (1968).

\section{Micromorphological studies}

Epidermal surface (stem and leaves) and nutlet surface of six Onosma species were studied by Tabletop Scanning Electron Microscopy (SEM). For SEM, small pieces of leaves and stem with nutlet were fixed on aluminum stubs using double-sided adhesive, and coated with gold palladium 
to a thickness of $40-50 \mathrm{~nm}$. The SEM micrographs were taken in a NeoScope JCM-5000 at an accelerating voltage of $10 \mathrm{kV}$ (Selvi et al., 2013). SEM studies took place in the Basic Sciences Research and Applied Center of Balıkesir University, Turkey.

Table 1. List of Onosma L. species along with their locality and voucher specimens.

\begin{tabular}{|c|c|c|c|}
\hline Species & Turkish name & Locality & Vouchers \\
\hline $\begin{array}{l}* O \text {. argentata } \\
\text { Hub.-Mor. }\end{array}$ & Gümüşemcek & $\begin{array}{l}\text { Turkey, B8 Bingöl: between Bingöl and Elazı ̆̆, } \\
\text { limestone slopes, } 39^{\circ} 34^{\prime} 48.05^{\prime \prime N}, 39^{\circ} 58^{\prime} 1.07 " E, 1505 \\
\text { m, 06.07.2017. }\end{array}$ & UC-2012 \\
\hline$* O$. neglecta Riedl & Bahaemziği & $\begin{array}{l}\text { Turkey, B8 Bingöl: between Kuruca and Karakoçan, } \\
\text { roadsides, } 38^{\circ} 55^{\prime} 21.30^{\prime \prime} \mathrm{N}, 40^{\circ} 19^{\prime} 57.28^{\prime \prime} \mathrm{E}, 1540 \mathrm{~m} \text {, } \\
\text { 09.07.2016. }\end{array}$ & UC-2013 \\
\hline $\begin{array}{l}\text { *O. proballanthera } \\
\text { Rech. f. }\end{array}$ & Yaylaemziği & $\begin{array}{l}\text { Turkey, B8 Bingöl: from Bingöl to Solhan roadsides, } \\
\text { rocky slopes, } 38^{\circ} 49^{\prime} 32.90^{\prime \prime N}, 40^{\circ} 51^{\prime} 33.85 " \mathrm{E}, 1898 \mathrm{~m} \text {, } \\
\text { 11.07.2016. }\end{array}$ & UC-2016 \\
\hline $\begin{array}{l}\text { *O. rechingeri } \\
\text { Riedl }\end{array}$ & Geçmijmıjok & $\begin{array}{l}\text { Turkey, B8 Bingöl: Genç town, towards from Genç to } \\
\text { Bingöl, limestone rocky, 3849'38.12"N, } \\
40^{\circ} 32^{\prime} 38.40^{\prime \prime} \mathrm{E}, 1070 \mathrm{~m}, 11.07 .2016 .\end{array}$ & UC-2015 \\
\hline O. sericea Willd. & Kâğıtemcek & $\begin{array}{l}\text { Turkey, B8 Bingöl: between Bingöl and Elaziğ, rocky } \\
\text { slopes, } 38^{\circ} 56^{\prime} 22.30^{\prime \prime N}, 40^{\circ} 10^{\prime} 24.28^{\prime \prime} \mathrm{E}, 1460 \mathrm{~m} \text {, } \\
\text { 10.07.2016. }\end{array}$ & UC-2014 \\
\hline $\begin{array}{l}* O . \text { stenoloba } \\
\text { Hausskn. ex Riedl }\end{array}$ & Tosyaemceği & $\begin{array}{l}\text { Turkey, B8 Bingöl: towards from Bingöl to Ilicalar } \\
\text { village, roadsides, } 39^{\circ} 11^{\prime} 12.57^{\prime \prime} \mathrm{N}, 40^{\circ} 44^{\prime} 18.84^{\prime \prime} \mathrm{E}, 1385 \\
\mathrm{~m}, 12.07 .2016 .\end{array}$ & UC-2017 \\
\hline
\end{tabular}

*Denotes species endemic to Turkey.

\section{Results and Discussion}

\section{Anatomical studies}

Anatomical investigation reveals variation in stem, lamina and midvein structure among the Onosma species investigated. A comparative account of biometric measurement of stem anatomy of the investigated species is provided in Table 2. At the outermost level, the cuticle layer ranges from $0.6 \mu \mathrm{m}$ in $O$. argentata to $1.7 \mu \mathrm{m}$ in $O$. proballanthera and $O$. sericea. The epidermal layer is lowest in $O$. sericea, while it is highest in $O$. neglecta. The maximum pith/stem ratio has been observed in $O$. neglecta $(0.69)$ followed by $O$. proballanthera $(0.68)$, whereas the minimum ratio (0.59) has been noticed in $O$. sericea (Table 2). Though no significant differences in stem cells in the investigated species have been observed, however, these features are found useful to some extent for distinguishing some species.

Single layered epidermal tissue consisting of oval, cubic or rectangular cells are found below the cuticle. In the epidermis, a few number of eglandular and rarely glandular trichomes are seen. Eglandular trichomes comprises 1-3 cells, upright or slightly curled, while glandular trichomes consist of 1-2 capitate stem cells with a round head. Cortex layer consists of collenchyma, parenchyma and endodermis, and at the top of the cortex layer 3-6-rows of collenchyma layers are found which is followed by 2-5 layered parenchyma cells. The parenchymatous cells of $O$. neglecta and $O$. stenoloba contain more intense starch than the remaining species. In the inner part of the cortex, there are 1-2 layered endodermis, and 3-layered phloem are observed below the endodermis. The cambium between phloem and xylem is often indistinguishable. Xylem in the 


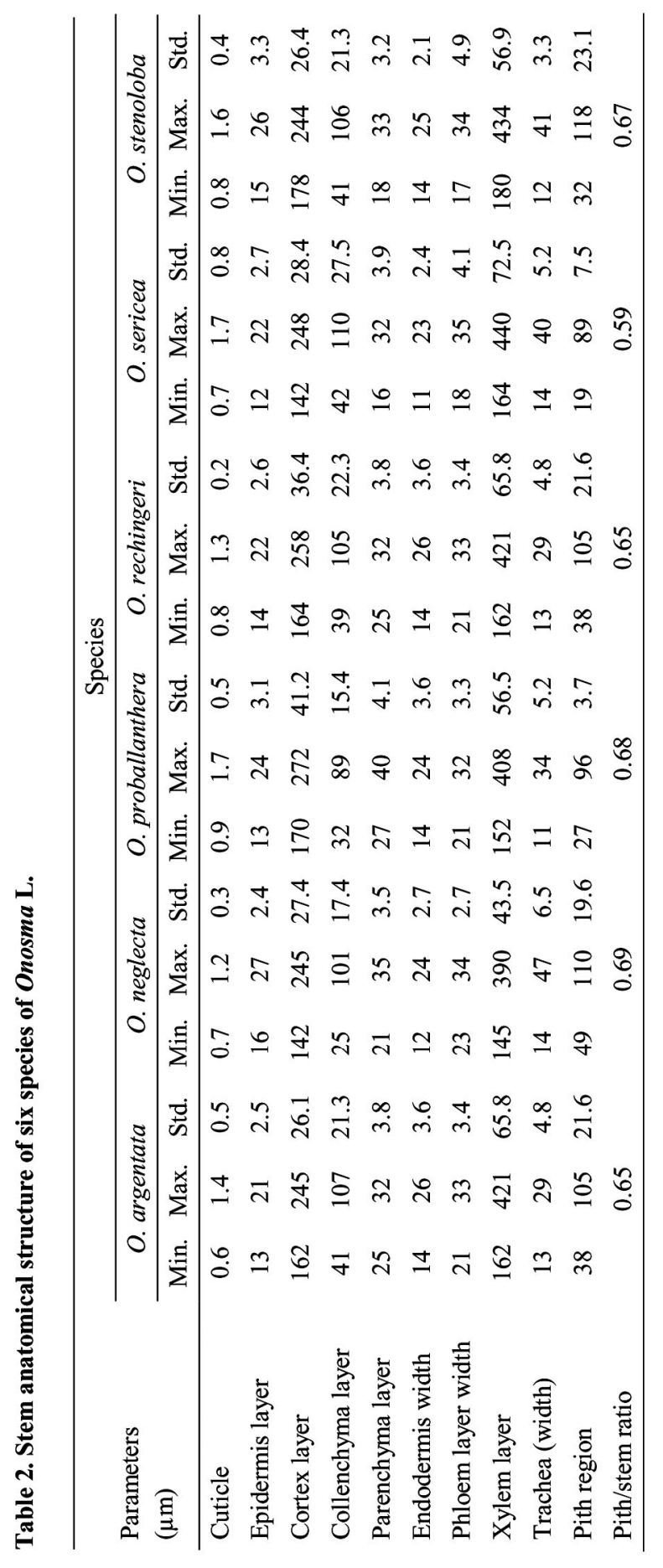


form of bundles towards pith, along with some regions with phloem is interrupted by the annulus to the pith. The pith region consists of round or polygonal parenchymatous cells with thin walls and fragmented (Fig. 1). In the cross section of leaf, the cuticle layer varies from $0.8 \mu \mathrm{m}$ in $O$. neglecta to $2.7 \mu \mathrm{m}$ in $O$. rechingeri. The longest palisade parenchymatous cell has been found in $O$. neglecta followed by $O$. stenoloba. In contrast, the smallest palisade parenchyma is noted in $O$. argentata. The length of palisade parenchyma remains the same in $O$. proballanthera and $O$. sericea (Table 3).
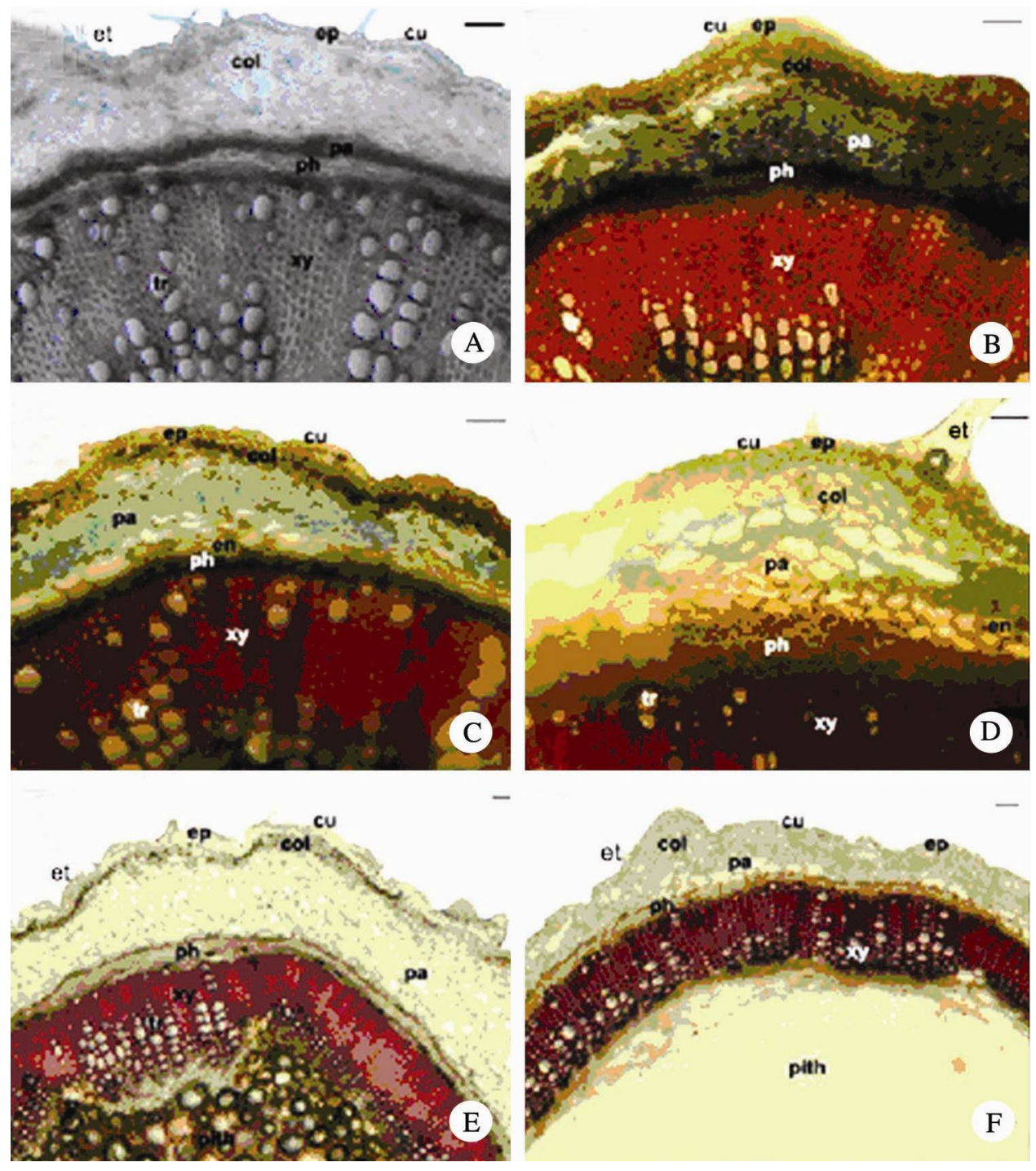

Fig. 1. Cross section of stem of six Onosma species: A. O. argentata; B. O. neglecta; C. O. proballanthera; D. O. rechingeri; E. O. sericea; F. O. stenoloba. cu: cuticle, ep: epidermis, et: eglandular trichome, col: collenchyma, pa: parenchyma, ph: phloem, xy: xylem, tr: trachea $(\operatorname{Bar}=50 \mu \mathrm{m})$. 


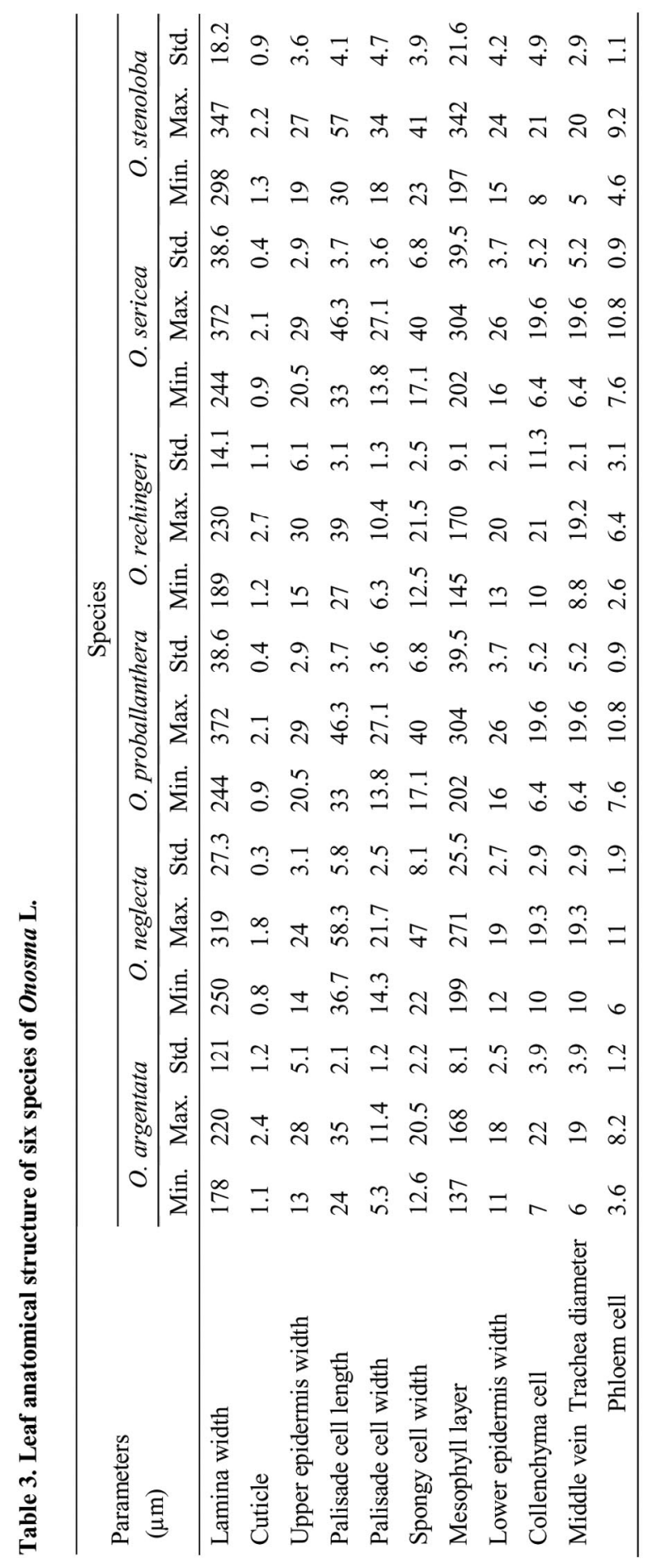


The upper and lower epidermis of leaves are covered with a thin cuticule in all the species studied. The upper epidermal cells are more significant than the lower ones. Epidermal cells consist of a single-row, tightly lined, rectangular, square and oval-shaped cells. The epidermis is densely covered with eglandular trichomes, and rarely with glandular trichomes. The eglandular trichomes are tubercled, 1-3 celled, straight or slightly curved shape, whereas the glandular trichomes are rare and capitate. The study also reveals variation in mesophyll structure among the species. $O$. argentata, $O$. sericea and $O$. rechingeri exhibit equifacial (isobilateral) type of leaves, while $O$. neglecta, $O$. proballanthera and $O$. stenoloba have bifacial (dorsiventral) leaves (Fig. 2).
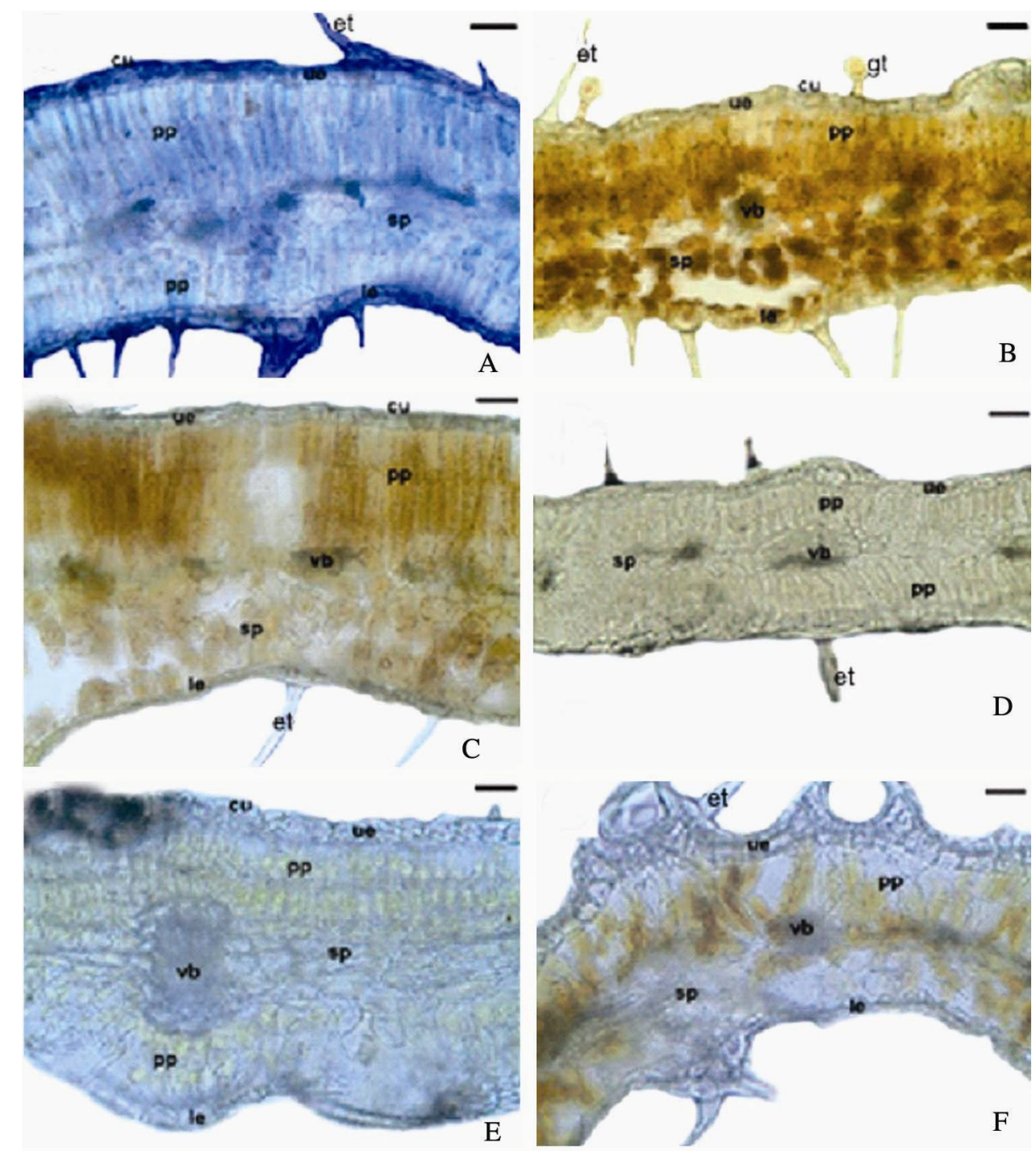

Fig. 2. Lamina mesophyll layer of six Onosma species: A. O. argentata; B. O. neglecta; C. $O$. proballanthera; D. O. rechingeri; E. $O$. sericea; F. $O$. stenoloba. cu: cuticle, ue: upper epidermis, et: eglandular trichome, gt: glandular trichome, pp: palisade parenchyma, sp: spongy parenchyma, vb: vascular bundle, le: lower epidermis $(\mathrm{Bar}=50 \mu \mathrm{m})$. 
This feature has been found important for distinguishing the species of Onosma. In the middle vein region, collateral type of vascular bundle (closed collateral) has been found in all the species. There are several subsequent collenchyma layers at the top of the xylem and below the phloem (Fig. 3).
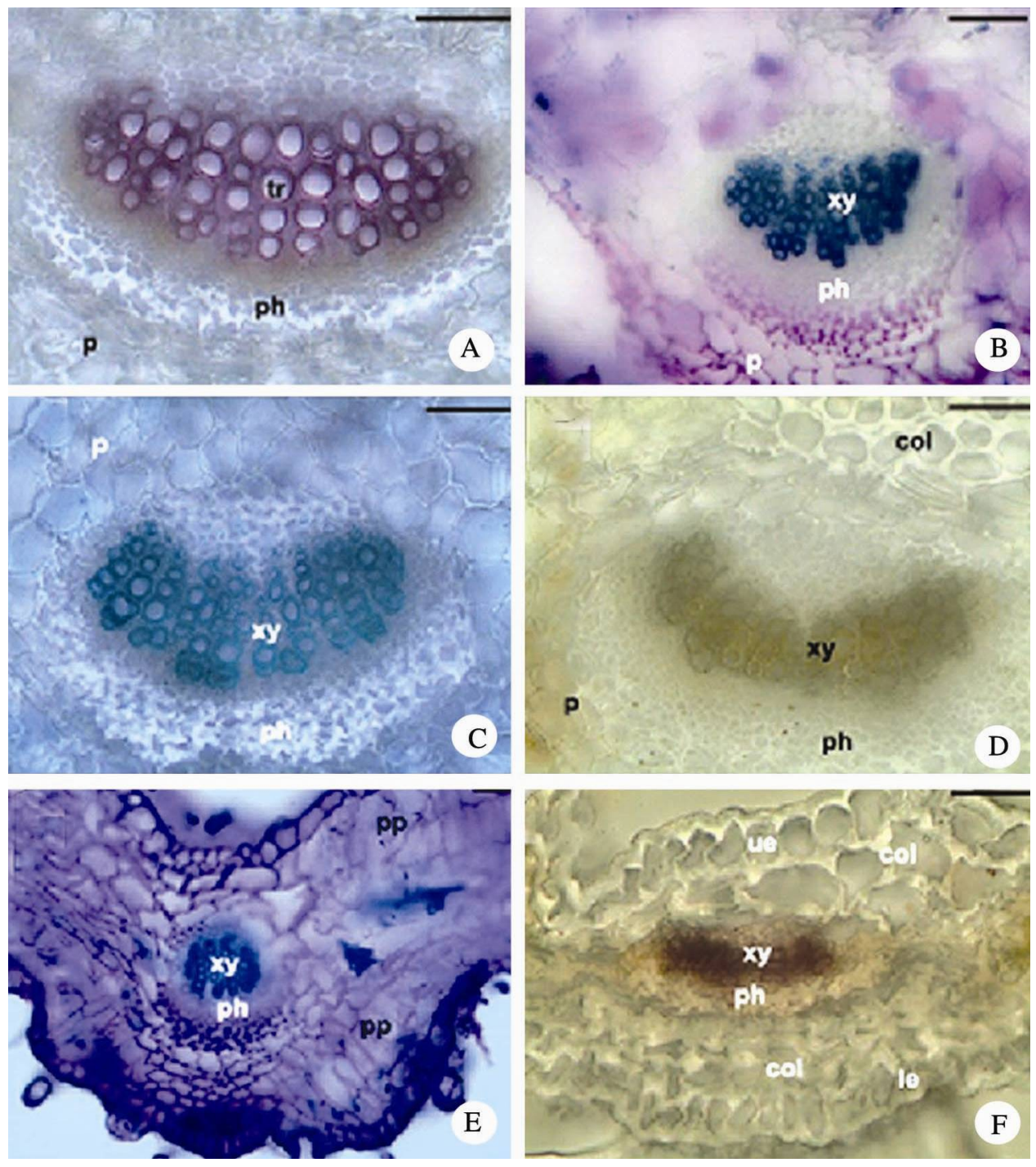

Fig. 3. Lamina middle veins of six Onosma species: A. O. argentata; B. O. neglecta; C. O. proballanthera; D. O. rechingeri; E. O. sericea; F. O. stenoloba. col: collenchyma, p: parenchyma, ph: phloem, xy: xylem, tr: trachea $(\mathrm{Bar}=50 \mu \mathrm{m})$.

The palisade parenchyma consist of two layers with plentiful chloroplasts which are cylindrical and tight. The spongy parenchyma is oval or round with $2-4$ rows, and are loosely arranged. In the middle vein region, there is a wide closed collateral type of vascular bundle. Underneath of the xylem there are 2-4 rows of phloem. Above of middle vein 1-2 rows of 
collenchyma layers are noticed, and 2-4 rows are observed below the middle vein. Stomata is found both in upper and lower surface of leaf (Amphistomatic). Anomocytic and anisocytic types of stomata are found in the investigated species (Fig. 4). Tissues and cells in stem and lamina of all investigated species have been found to contain calcium oxalate crystals, either in solitary or in clustered form. Cystoliths are frequent in the basal parts of hairs.
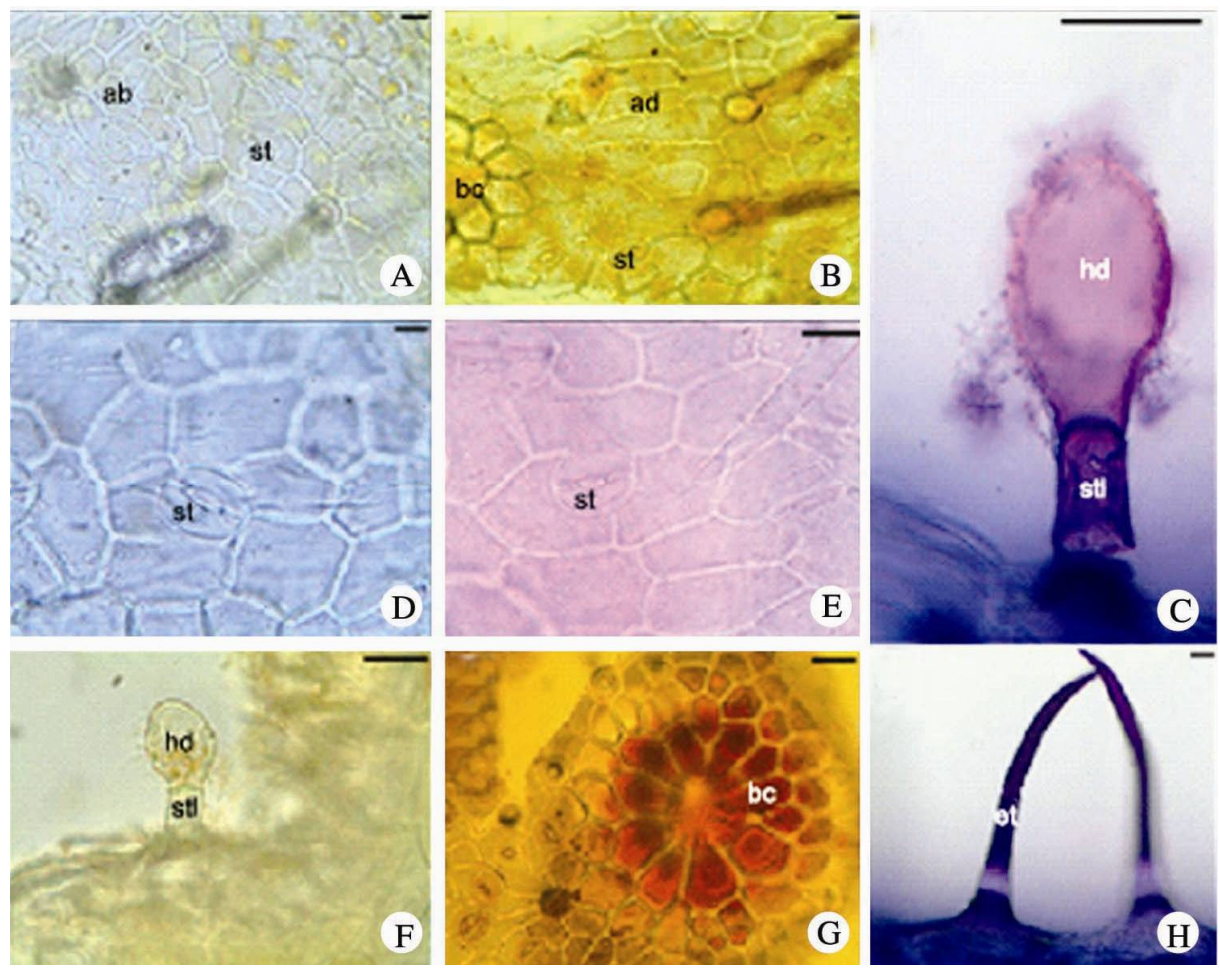

Fig. 4. Epidermal surface of six Onosma species: A. Lamina-abaxial surface (O. proballenthera); B. Laminaadaxial surface $(O$. sericea); C. Capitate trichome $(O$. neglecta); D. Anomocytic stomata $(O$. proballenthera); E. Anisocytic stomata $(O$. neglecta); F. Capitate trichome on lamina (O. rechingeri); G. Base cells of seta $(O$. argentata); H. Eglandular trichomes (setae) on lamina (O. neglecta). st: stomata, ad: adaxial surface, ab: abaxial surface, hd: head cell, stl: stalk, et: eglandular trichome; bc: trichome base cell $(\mathrm{Bar}=20 \mu \mathrm{m})$.

\section{Micromorphological studies}

Epidermal surface of stem and leaves, and nutlet surface of six Onosma species have been investigated by SEM. Micromorphological studies have shown that both stem and leaves contain dense eglandular and sparsely glandular trichomes. Eglandular trichomes are usually 1-2 celled, straight or slightly curled. The glandular trichomes are less common, consisting of a 1-2 stem cells with a round head (Fig. 4). Trichomes play an important role in identifying the members of the family Boraginaceae. Metcalfe and Chalk (1950) have shown that distribution and forms of trichomes are useful to differentiate between the different genera and taxa of the family Boraginaceae.

The stem and leaf epidermal surfaces of the Onosma species in our study are heavily covered with feathers (setae) and rarely glandular trichomes. Tubercled long trichomes on leaves contain 
beams at the base of $O$. stenoloba. Unlike other species, on the leaf surfaces of $O$. rechingeri, there are simple hairs with pointed or lying ends. At the bottom of some setae, large cells containing cystolith are observed (Fig. 4). The indumentum structure of the stem and leaves differ according to the tubercles of the setae. If the tubercles are glabrous they are haplotrichous, and when tubercles stellately at base are asterotrichous. Based on indumentum structure, O. stenoloba can easily be distinguished from all other species as it is asterotrichous, whereas, the remaining Onosma species have haplotrichous type of indumentum (Fig. 4). The most excessive glandular trichomes have been found in the leaves of the O. rechingeri and O. neglecta. The trichome is made up of a pear-shaped head cell and a single or two-celled stem cell. Stomata have been found intensely and usually are of anomocytic in all species, however, anisocytic stomata are found seldomly in $O$. neglecta and $O$. stenoloba. Akçin et al. (2013) examined the stomata of $O$. sericea and $O$. stenoloba and found anomocytic and anisocytic types of stomata in these species. In our study, anisocytic stomata have been found in both of these two species, however, the anomocytic stomata has been observed only in $O$. stenoloba.

The nutlet micromophology of six Onosma species are presented in Table 4. Nutlets of the studied Onosma species vary in size and shape. The smallest nutlets $(2.5-3.6 \times 2.5-3.5 \mathrm{~mm})$ are found in $O$. stenoloba, while the largest nutlets $(3.9-4.3 \times 3.2-3.7 \mathrm{~mm})$ are observed in $O$. rechingeri. Different shapes of nutlets are found in the examined species, viz. oblong-ovoid $(O$. rechingeri, $O$. stenoloba), ovoid (O. argentata, $O$. neglecta, $O$. sericea), and orbicular to ovoid $(O$. proballanthera). In the nutlets of $O$. neglecta, $O$. rechingeri and $O$. stenoloba sharp ventral keels are seen. Two types of ornamentation of nutlets have been determined - the rugose type and the reticulate type. Rugose type is characterised by the epidermal cells of the nutlet surface having small or fine wrinkles, and this type of ornamentation has been observed in $O$. argentata, $O$. neglecta and $O$. sericea. The reticulate type is characterised by the epidermal cells of the nutlet surface which are formed in a reticulate ornamentation with varied sizes and shapes of mesh, and this type of ornamentation has been found in $O$. proballanthera, O. rechingeri and $O$. stenoloba (Fig. 5 and Table 4). Binzet and Akçin (2009) found some variations in nutlet surfaces of 14 Onosma species and determined four main types of surface ornamentation, viz. ruminate, rugose, reticulate and pusticulate. Among those four types we found only rugose and reticulate types of ornamentation in our study.

Table 4. Nutlet characters of six species of Onosma $\mathbf{L}$.

\begin{tabular}{|c|c|c|c|c|}
\hline Species & $\begin{array}{l}\text { Nutlet size } \\
(\mathrm{mm})\end{array}$ & Shape & Color & $\begin{array}{l}\text { Epidermal } \\
\text { cell }\end{array}$ \\
\hline O. argentata & $3.3-3.8 \times 2.7-3.0$ & $\begin{array}{l}\text { Ovoid, acute; dorsal side convex, } \\
\text { ventral side roof-like }\end{array}$ & Brownish & Rugose \\
\hline O. neglecta & $3.5-4.4 \times 2.75-3.4$ & $\begin{array}{l}\text { Ovoid, with prominent beak; dorsal } \\
\text { side convex, ventral side keeled }\end{array}$ & $\begin{array}{l}\text { Chestnut- } \\
\text { brown }\end{array}$ & Rugose \\
\hline O. proballanthera & $3.7-4.5 \times 2.8-3.6$ & $\begin{array}{l}\text { Orbicular to ovoid, with prominent } \\
\text { beak; dorsal side convex, ventral } \\
\text { side weakly keeled }\end{array}$ & $\begin{array}{l}\text { Light } \\
\text { brown }\end{array}$ & Reticulate \\
\hline O. rechingeri & $3.9-4.3 \times 3.2-3.7$ & $\begin{array}{l}\text { Oblong- ovoid, acute; dorsal side } \\
\text { convex, ventral side keeled }\end{array}$ & Brownish & Reticulate \\
\hline O. sericea & $3.6-4.5 \times 2.3-3.5$ & $\begin{array}{l}\text { Ovoid, acute; dorsal side convex, } \\
\text { ventral side roof-like }\end{array}$ & Brownish & Rugose \\
\hline O. stenoloba & $2.5-3.6 \times 2.5-3.5$ & $\begin{array}{l}\text { Oblong-ovoid, acute; dorsal side } \\
\text { convex, ventral side keeled }\end{array}$ & Brownish & Reticulate \\
\hline
\end{tabular}


Micromorphological characters of epidermal surface of stem and leaf as revealed from scanning electron microscopy are shown in Fig. 6. Eglandular and glandular trichomes have been observed in the stem and leaves of all species investigated. Glandular trichomes were less frequent than eglandular trichomes. Eglandular trichomes are rigid, unicelluar and patent-setose in all
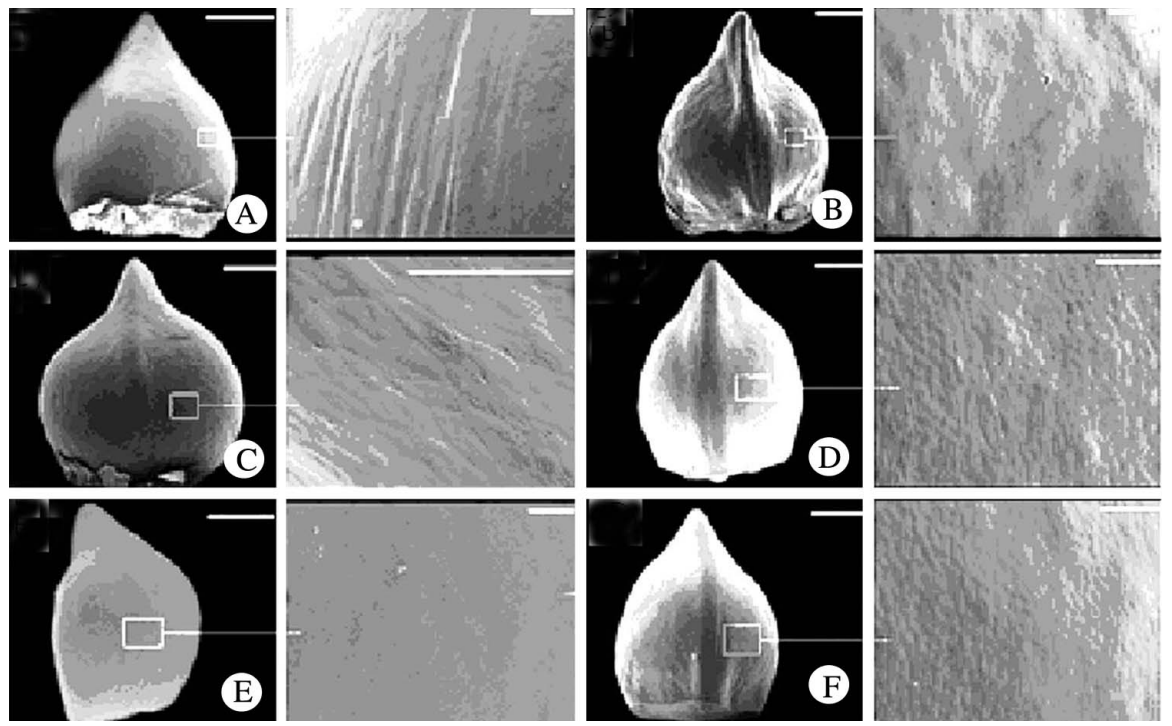

Fig. 5. Seed micromorphology of six Onosma species: A. O. argentata; B. O. neglecta; C. O. proballanthera; D. O. rechinger; E. O. sericea; F. O. stenoloba (Bar $=1 \mathrm{~mm}$ (general view), $100 \mu \mathrm{m}$ (surface ornamentation).

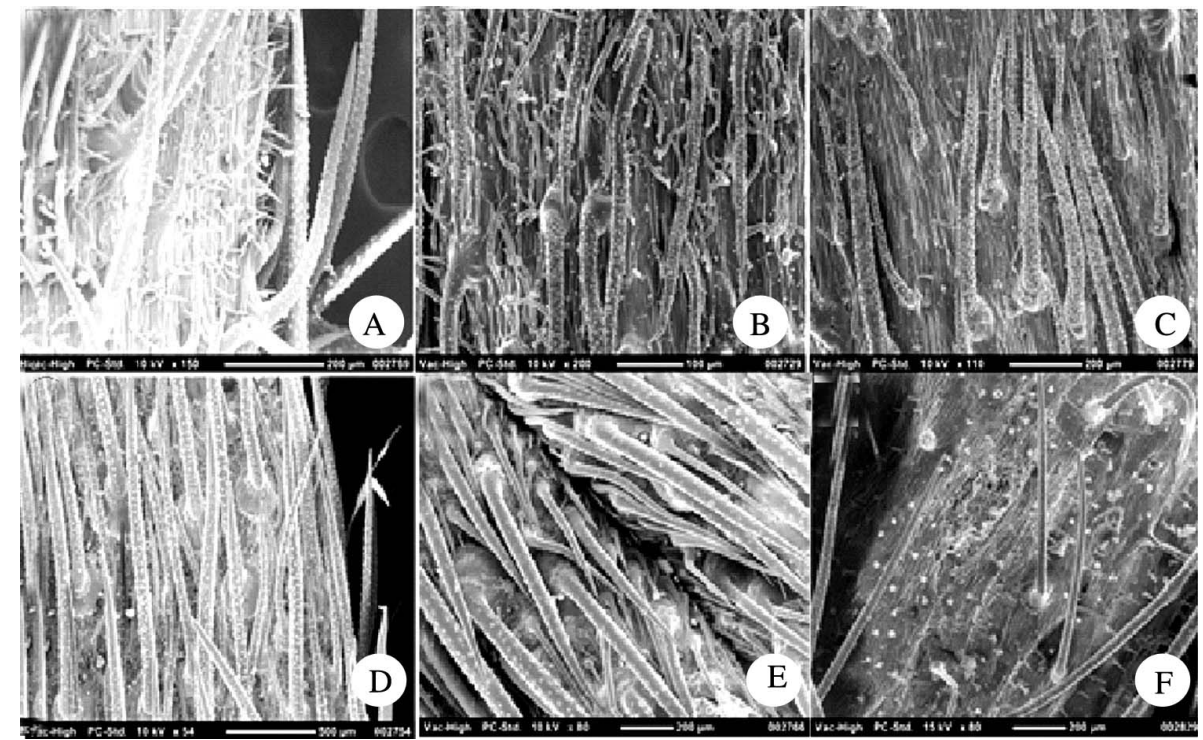

Fig. 6. Micromorphology of epidermal surface (stem and leaves) of Onosma species by SEM: Stem (A,B,C), Leaves (D,E,F): A. O. argentata; B. O. rechingeri; C. O. stenoloba; D. O. neglecta; E. O. sericea; F. O. proballanthera. $($ Bar $=200 \mu \mathrm{m})$. 
species. Glabrous tubercules have been found at the base of stem and leaf of all species except $O$. stenoloba. The setae surface of those species cover dense or sparse papilae, where setae of $O$. stenoloba consist of tubercles with pilies at the base. The findings based on anatomical and micromorphological studies were found somewhat consistent with those of Akçin and Engin (2001), and Akçin and Binzet (2010). However, our results differs from those earlier studies in terms of number of layers of cells and tissues, the density of trichomes and the types of leaf mesophyll (Fig. 6). The present study based on micromorphological and anatomical investigation employing six Onosma species, of which five are endemic to Turkey, is the first of its nature. Though there are similarities in micromorphology and anatomy of stem, leaf and nutlets among

the species studied, however, some of these characters have been found useful for delimation of the species. More particularly, micromorphological features of nutlet surface of Onosma, anatomical features of epidermal surface (trichomes and stomata), and types of lamina mesophyll (dorsiventral and isobilateral) could be useful in species delimitation and solving taxonomic problem of the genus.

\section{Acknowledgement}

The financial support from the Scientific Investigation Project Coordinator of Munzur University (Project number: MFTUB 015-024) is gratefully acknowledged.

\section{References}

Akçin, Ö.E. 2004. An investigation on the morphology, anatomy and ecology of endemic Onosma bornmuelleri Hausskn. Ecology 13: 13-19.

Akçin, Ö.E. 2007. Nutlets micromorphology of some Onosma L. (Boraginaceae) species from Turkey. Biologia 62: 684-689.

Akçin, Ö.E. 2009. Micromorphological and anatomical studies on petals of 11 Turkish Onosma L. (Boraginaceae) taxa. Bangladesh J. Plant Taxon. 16(2): 157-164.

Akçin, Ö.E. and Binzet, R. 2010. The micromorphological and anatomical properties of Onosma angustissimum Hausskn. \& Bornm. and O. cassium Boiss. (Boraginaceae). Bangladesh J. Plant Taxon. 17(1): 1-8.

Akçin, Ö.E. and Engin, A. 2001. Comparative morphological and anatomical study on species of Onosma isauricum Boiss. \& Heldr. and O. stenolobum Hausskn. ex H. Riedl. Herb J. Syst. Bot. 8: 75-95.

Akçin, Ö.E. and Engin, A. 2005. The morphological, anatomical and ecological properties of endemic Onosma bracteosum Hausskn. \& Bornm. (Boraginaceae) species. Turkish J. Bot. 29: 317-325.

Akçin, Ö.E, Şenel, G. and Akçin, Y. 2013. Leaf epidermis morphology of some Onosma (Boraginaceae) species from Turkey. Turkish J. Bot. 37: 55-64.

Begum, A., Rahman, M.O. and Begum, M. 2014. Stomatal and trichome diversity in Senna Mill. from Bangladesh. Bangladesh J. Plant Taxon. 21(1): 43-51.

Binzet, R. 2016. Onosma anatolica, a new species of Boraginaceae from Turkey. PhytoKeys 69: 39-49.

Binzet, R. and Akçin, Ö.E. 2009. Nutlet size, shape and surface ornamentation in 14 Onosma species (Boraginaceae). Acta Bot. Croatica 68(1): 117-126.

Binzet, R., Kandemir, İ. and Orcan, N. 2010. Palynological classification of Onosma L. (Boraginaceae) species from East Mediterranean region in Turkey. Acta Bot. Croatica 69: 259-274.

Cecchi, L. and Selvi, F. 2009. Phylogenetic relationships of the monotypic genera Halacsya and Paramoltkia and the origins of serpentine adaptation in circummediterranean Lithospermeae (Boraginaceae): Insights from ITS and matK DNA sequences. Taxon 58: 700-714.

Cronquist, A. 1981. The Evolution and Classification of Flowering Plants. Second edition, London.

Dukas, R. and Dafni, A. 1990. Buzz - Pollination in three nectariferous Boraginaceae and possible evolution of buzz-pollinated flowers. Plant Syst. Evol. 169: 65-68. 
Güner, A., Aslan, S., Ekim, T., Vural, M. and Babac, M.T. 2012. Türkiye bitkileri listesi (Damarlı bitkiler). Nezahat Gökyiğit Botanik Bahçesi ve Flora Araştırmaları Derneği Yayını: İstanbul.

Hayta, S., Polat, R. and Selvi, S. 2014. Traditional uses of medicinal plants in Elazig (Turkey). J. Ethnopharmacol. 154: 613-623.

Kolarcik, V., Zozomova-Lihova, J. and Martonfi, P. 2010. Systematic and evolutionary history of the Asterotricha group of the genus Onosma (Boraginaceae) in central and southern Europe inferred from AFLP and nrDNA ITS data. Plant Syst. Evol. 290: 21-45.

Mehrabian, A.R., Sheidai, M. and Mozaffarian, V. 2014. Micromorphology of leaf trichomes in Onosma (Boraginaceae) and their systematic relevance in Iran. Phytol. Balcan. 20: 33-48.

Meidner, H. and Mansfield, T.A. 1968. Physiology of Stomata. McGraw-Hill, New York.

Meng, L. and Mao, P. 2013. Micromorphological and anatomical features of four species of Elytrigia Desv. (Poaceae). Bangladesh J. Plant Taxon. 20(2): 135-144.

Metcalfe, C.R. and Chalk, L. 1950. Anatomy of Dicotyledons. Clarendon, Oxford.

Özgen, U., Çoşkun, M., Kazaz, C. and Seçen, H. 2004. Naphthoquinones from the roots of Onosma argentatum Hub.-Mor. (Boraginaceae). Turkish J. Chem. 28: 451-454.

Riedl, H. 1967. Boraginaceae. In: Rechinger, K.H. (Ed.), Flora Iranica, 48. Akademische Druck- und Verlagsanstalt, Graz, pp. 1-281.

Rieldl, H. 1978. Boraginaceae. In: Davis, P.H. (Ed.), Flora of Turkey and the East Aegean Islands. Edinburgh: Edinburgh University Press, Edinburgh, UK, 6: 237-437.

Selvi, S., Açar, M. and Sat1l, F. 2013. Comparative micromorphological and anatomical investigations on Thymus pulvinatus and $T$. cherlerioides var. cherlerioides in Kazdağı Mount (EdremitBalıkesir/Turkey). Biodicon 6(3): 12-20.

Selvi, S., Paksoy, M.Y., Polat, R. and Cakilcioglu, U. 2014. Micromorphological and anatomical characteristics of the genus Chrysophthalmum Schultz Bip. (Asteraceae) growing in Turkey. Proceed. Nat. Acad. Sci., India Sect. B, Biol. Sci. 4: 431-438.

Tschan, G.F. and Denk, T. 2012. Trichome types, foliar indumentum and epicuticular wax in the Mediterranean gall oaks, Quercus subsection Galliferae (Fagaceae): implications for taxonomy, ecology and evolution. Bot. J. Linn. Soc. 169: 611-644.

Yakar-Tan, N. 1982. Bitki Mikroskopisi Klavuz Kitab1. Istanbul University, Faculty of Science Publishing, Istanbul, Turkey.

(Manuscript received on 5 February 2019; revised on 27 April 2019) 